\title{
Association between chymase gene polymorphisms and atrial fibrillation in Chinese Han population
}

\author{
Dongchen Zhou, Yuewei Chen, Jiaxin Wu, Jiabo Shen, Yushan Shang, Liangrong Zheng and Xudong Xie* (D)
}

\begin{abstract}
Background: Chymase is the major angiotensin II (Ang II)-forming enzyme in cardiovascular tissue, with an important role in atrial remodeling. This study aimed to examine the association between chymase 1 gene (CMA1) polymorphisms and atrial fibrillation (AF) in a Chinese Han population.

Methods: This case-control study enrolled 126 patients with lone AF and 120 age- and sex-matched healthy controls, all from a Chinese Han population. Five CMA1 polymorphisms were genotyped.

Results: The CMA1 polymorphism rs1800875 (G-1903A) was associated with AF. The frequency of the GG genotype was significantly higher in AF patients compared with controls $(p=0.009)$. Haplotype analysis further demonstrated an increased risk of AF associated with the rs1800875-G haplotype (Hap8 TGTG, odds ratio (OR) $=1.668,95 \% \mathrm{Cl}$ $1.132-2.458, p=0.009$ ), and a decreased risk for the rs1800875-A haplotype (Hap5 TATTG, OR $=0.178,95 \% \mathrm{Cl} 0.042-$ $0.749, p=0.008)$.
\end{abstract}

Conclusions: CMA1 polymorphisms may be associated with AF, and the rs1800875 GG genotype might be a susceptibility factor for AF in the Chinese Han population.

Keywords: Atrial fibrillation, CMA1, Chymase, Single nucleotide polymorphism, Angiotensin II

\section{Background}

Atrial fibrillation (AF) is the most common type of sustained clinical arrhythmia and is associated with significant cardiovascular morbidity and mortality. However, despite its clinical significance and high prevalence, the molecular basis of AF remains unclear. Diverse structural heart diseases and systemic disorders have been associated with AF, including valvular heart disease, ischemic heart disease, congestive heart failure, cardiomyopathy, pulmonary heart disease, cardiothoracic surgery, essential hypertension, and hyperthyroidism [1, 2], while age, obesity, obstructive sleep apnea-hypopnea syndrome, smoking, excessive drinking, and drug or toxicant use are also considered to contribute to the development of AF $[1,3]$. However, AF outcomes differ among individuals with similar pathologies and comorbidities. Furthermore, up to a third of AF cases, termed

\footnotetext{
* Correspondence: xiexdzju@163.com

Department of Cardiology, First Affiliated Hospital, School of Medicine,

Zhejiang University, Hangzhou, China
}

'lone AF', occur in the absence of identifiable underlying cardiovascular or other comorbid diseases [4]. The Framingham Heart Study showed that $30 \%$ of participants with $\mathrm{AF}$ had at least one parent with $\mathrm{AF}$, and individuals with at least one parent suffering from AF had an approximately $40 \%$ increased risk of developing AF, after adjusting for age, sex, blood pressure, diabetes, and clinically overt heart disease [5]. These facts indicate a potential role for genetic variations in the pathogenesis of AF. Genome-wide association studies have identified common genetic variants associated with $\mathrm{AF}$, and a recent report found three independent single nucleotide polymorphisms (SNPs) (rs2200733, rs17570669, and rs3853445) associated with increased AF risk [6]. Nevertheless, the genetic basis of AF pathogenesis is complex, involving modest contributions to disease risk from genetic variations in many genes, and further studies are needed to clarify the genetic determinants of AF risk.

The renin-angiotensin system (RAS) is involved in multiple pathophysiological processes in cardiovascular

(c) The Author(s). 2019 Open Access This article is distributed under the terms of the Creative Commons Attribution 4.0 International License (http://creativecommons.org/licenses/by/4.0/), which permits unrestricted use, distribution, and reproduction in any medium, provided you give appropriate credit to the original author(s) and the source, provide a link to the Creative Commons license, and indicate if changes were made. The Creative Commons Public Domain Dedication waiver (http://creativecommons.org/publicdomain/zero/1.0/) applies to the data made available in this article, unless otherwise stated. 
diseases and plays an important role in the development of AF [7]. Angiotensin II (Ang II) is the primary active component of RAS [8]. There is growing evidence to indicate that cardiac Ang II formation depends largely on the serine protease chymase [9], which is present in specific tissues, including the cardiac interstitium and blood vessels $[10,11]$, and converts angiotensin (1-12) to Ang II. Due to the difficulty in obtaining the samples of human heart tissue, most of the studies on chymase and Ang II are animal experiments. Most rodents, such as the mouse, rat, rabbit and pig, have $\beta$-chymase isoform in addition to $\alpha$-chymase [12-14]. Humans only express the $\alpha$-chymase. So the current experimental studies may not really represent the human condition. Chymase 1 (CMA1) gene is located on the long arm of chromosome 14 [15], and polymorphisms in CMA1 have been reported to be associated with asthma, heart failure, and even aortic stenosis [15-17]. Many animal studies showed the benefits of chymase inhibitors to the cardiovascular system, such as preventing vascular proliferation [18], improving cardiac function [19] and inhibiting cardiovascular remodeling [20], etc., although studies in human body are still relatively rare. Chymase inhibitors have been shown to suppress cardiac remodeling and myocardial fibrosis [20], which are sufficient substrates for AF. However, the association between CMA1 polymorphisms and AF has not yet been reported. In this study, we investigated the association between CMA1 polymorphisms and AF with the aimed of identifying possible genetic variants of CMA1 that may predispose individuals to the risk of $\mathrm{AF}$ in the Chinese Han population.

\section{Methods}

\section{Subjects}

Lone AF was defined as AF without clinical or echocardiographic findings of cardiovascular diseases, hypertension, or metabolic or pulmonary diseases [21]. A total of 126 consecutive patients with lone AF admitted to the Department of Cardiology at the First Affiliated Hospital, School of Medicine, Zhejiang University, were recruited from January 2014 to December 2015. A group of 120 healthy age- and sex-matched individuals were enrolled as controls. The controls were recruited mainly for people with the habit of regular physical examination, so as to obtain more detailed and accurate history of past and present diseases. Both the case and control groups comprised Chinese Han individuals, all of whom had undergone clinical evaluation and echocardiographic examination. Patients' medication included only agents to treat atrial fibrillation, such as amiodarone, digoxinum, or metoprolol, or anticoagulant drugs such as warfarin or rivaroxaban, and so on. All patients provided signed informed consent. The study conformed to the principles of the Declaration of Helsinki, and was approved by the Ethics Committee of the First Affiliated Hospital, School of Medicine, Zhejiang University (2016496). All serum samples and peripheral blood leukocytes were stored at $-80^{\circ} \mathrm{C}$ for further measurements.

\section{Polymorphism identification and genotype analysis}

We identified five SNPs (rs1800875, rs1800876, rs1885108, rs1956921 and rs5244) in the CMA1 gene, according to previous studies [22]. Genomic DNA was extracted from peripheral blood leukocytes as described previously [23]. Five SNPs were genotyped in all 246 subjects using polymerase chain reaction (PCR) and direct sequencing. The primers, annealing temperature, length of PCR products, and the specific procedures have been described previously $[22,24]$. The PCR products were subjected to PCR-direct sequencing using BigDye 3.1 chemistry and an ABI3500xl genetic analyzer (Applied Biosystems, Foster City, CA, USA), according to the manufacturer's protocol [17]. The results were analyzed using DNAStar software SeqMan (DNAStar, Madison, WI, USA).

\section{Statistical analysis}

Statistical analyses were performed using SPSS 22 software, with a value of $p<0.05$ considered to be significant. The data were generally expressed as rates and ratios. Continuous variables were described as mean \pm standard deviation. The Hardy-Weinberg equilibrium of each SNP was assessed by $x^{2}$ tests. Genotype and allele distributions were compared between AF patients and controls by $X^{2}$ tests. Odds ratios (ORs) were calculated using four-fold table $X^{2}$ analysis, and 95\% confidence intervals (95\% CI) and two-tailed $p$ values were determined for each OR. Comparisons between groups were made using twosample $t$-tests for continuous data. Only main haplotypes with frequencies $>1 \%$ were considered for further analysis. Possible associations between statistically inferred haplotypes and AF were calculated using SHEsis software (http://analysis.bio-x.cn/myAnalysis.php).

\section{Results}

\section{Clinical characteristics}

Table 1 shows the clinical characteristics of patients with controls and AF patients. As shown, patients with AF exhibited significantly lower total cholesterol (TC), and low density lipoprotein (LDL) compared to control subjects. There was no significant difference between the cases and controls for age, gender, BP, body mass index (BMI), triglyceride (TG) and glucose (Glu).

\section{Genotype and allele frequencies}

Five CMA1 SNPs were genotyped in healthy controls and AF patients, and the distributions of most of the loci 
Table 1 Baseline characteristics of the study subjects

\begin{tabular}{llll}
\hline Parameters & controls & AF & $p$-value \\
\hline Number & 120 & 126 & \\
Sex(male/female) & $77 / 43$ & $78 / 46$ & 0.837 \\
Age (years) & $54.80 \pm 12.99$ & $55.80 \pm 10.06$ & 0.502 \\
SBP (mm Hg) & $124.62 \pm 13.95$ & $124.45 \pm 15.32$ & 0.931 \\
DBP (mm Hg) & $76.35 \pm 8.71$ & $76.18 \pm 11.31$ & 0.898 \\
BMI (kg/m $\left.{ }^{2}\right)$ & $23.50 \pm 2.38$ & $23.80 \pm 3.30$ & 0.530 \\
TG $(\mathrm{mmol} / \mathrm{L})$ & $1.17 \pm 0.58$ & $1.30 \pm 0.60$ & 0.094 \\
TC $(\mathrm{mmol} / \mathrm{L})$ & $4.46 \pm 0.78$ & $4.12 \pm 0.86$ & 0.002 \\
LDL $(\mathrm{mmol} / \mathrm{L})$ & $2.54 \pm 0.60$ & $2.33 \pm 0.63$ & 0.010 \\
Glu $(\mathrm{mmol} / \mathrm{L})$ & $4.68 \pm 0.63$ & $4.67 \pm 0.63$ & 0.829
\end{tabular}

$B M I$ Body mass index, SBP Systolic blood pressure, DBP Diastolic blood pressure, TC Total cholesterol, TG Triglyceride, HDL High density lipoprotein, LDL Low density lipoprotein, Glu Glucose

except the rs1800876 in AF patients were in HardyWeinberg equilibrium $(p>0.05)$ (Table 2). The genotype and allele frequencies of the five polymorphisms in AF patients are listed in Table 2. The minor allele frequencies of each SNP in the healthy Chinese Han population were as follows: rs1800875, 30.83\%; rs1956921, 16.39\%; rs5244, 25.86\%; rs1800876, 37.82\%; and rs1885108, 41.67\% (Table 2).

The distribution of the rs1800875 (G-1903A) genotype differed significantly between AF patients and controls $(p=0.009)$. The observed genotype frequencies in AF patients and controls were 8.06 and $5.83 \%$ for AA, 30.65 and $50.00 \%$ for AG, and 81.29 and $44.17 \%$ for GG, respectively. The OR of the GG genotype for AF was 0.500 (95\%CI, 0.300-0.832; $p=0.007$ ). There were no significant differences in genotype or allele distributions for rs1800876, rs1885108, rs1956921, and rs5244 between the $\mathrm{AF}$ and control groups $(p>0.05)$.

\section{Haplotype analysis}

The CMA1 haplotypes were constructed according to their SNPs. Five CMA1 haplotypes had frequencies $>1 \%$ in both AF patients and controls (Table 3). The occurrence of Hap8 TGTTG was significantly higher in AF patients than in controls $(p=0.009)$, and four-fold table $X^{2}$ analysis indicated that this haplotype might be associated with increased genetic susceptibility to $\mathrm{AF}(\mathrm{OR}=$ 1.668, 95\% CI 1.132-2.458). In contrast, Hap5 TATTG had a significantly lower incidence in AF patients compared with controls $(p=0.008)$, indicating a reduced risk of $\mathrm{AF}(\mathrm{OR}=0.178,95 \% \mathrm{CI} 0.042-0.749)$.

\section{Discussion}

SNPs present in $>1 \%$ of the population are common in the human genome, and have been shown to affect gene function and influence susceptibility to certain diseases. Numerous recent studies have demonstrated that AF is

Table 2 Genotype and allele distributions in Atrial fibrillation patients and controls

\begin{tabular}{|c|c|c|c|c|c|c|c|c|c|c|c|c|c|}
\hline \multirow[t]{2}{*}{ Variant } & \multirow{2}{*}{$\begin{array}{l}\text { Allele } \\
1 / 2\end{array}$} & \multirow[t]{2}{*}{ Group } & \multirow[t]{2}{*}{$n$} & \multicolumn{3}{|c|}{ Genotype (frequency) } & \multirow[t]{2}{*}{$p$} & \multirow{2}{*}{$\begin{array}{l}\text { OR }(95 \% \mathrm{Cl}), p \\
1 / 1+1 / 2 \mathrm{vs} 2 / 2\end{array}$} & \multicolumn{2}{|c|}{ Allele (frequency) } & \multirow{2}{*}{$\begin{array}{l}\text { OR }(95 \% \mathrm{Cl}), p \\
1 \text { vs } 2\end{array}$} & \multicolumn{2}{|c|}{$\begin{array}{l}\text { Hardy- } \\
\text { Weinberg } \\
\text { equilibrium }\end{array}$} \\
\hline & & & & $\overline{1 / 1}$ & $1 / 2$ & $2 / 2$ & & & 1 & 2 & & $\overline{x^{2}}$ & $p$ \\
\hline \multirow[t]{2}{*}{ rs1956921 } & $\mathrm{C} / \mathrm{T}$ & $\mathrm{AF}$ & 126 & $\begin{array}{l}2 \\
(1.59 \%)\end{array}$ & $\begin{array}{l}25 \\
(19.84 \%)\end{array}$ & $\begin{array}{l}99 \\
(78.57 \%)\end{array}$ & 0.285 & $\begin{array}{l}0.629 \\
(0.353-1.212) 0.114\end{array}$ & $\begin{array}{l}29 \\
(11.51 \%)\end{array}$ & $\begin{array}{l}223 \\
(88.49 \%)\end{array}$ & $\begin{array}{l}0.664(0.396- \\
1.113) 0.118\end{array}$ & 0.084 & 0.7719 \\
\hline & & controls & 119 & $\begin{array}{l}3 \\
(2.52 \%)\end{array}$ & $\begin{array}{l}33 \\
(27.73 \%)\end{array}$ & $\begin{array}{l}83 \\
(69.75 \%)\end{array}$ & & & $\begin{array}{l}39 \\
(16.39 \%)\end{array}$ & $\begin{array}{l}199 \\
(83.61 \%)\end{array}$ & & 0.017 & 0.8960 \\
\hline \multirow[t]{2}{*}{ rs1800875 } & $\mathrm{A} / \mathrm{G}$ & $\mathrm{AF}$ & 124 & $\begin{array}{l}10 \\
(8.06 \%)\end{array}$ & $\begin{array}{l}38 \\
(30.65 \%)\end{array}$ & $\begin{array}{l}76 \\
(81.29 \%)\end{array}$ & 0.009 & $\begin{array}{l}0.500(0.300-0.832) \\
0.007\end{array}$ & $\begin{array}{l}58 \\
(23.39 \%)\end{array}$ & $\begin{array}{l}190 \\
(76.61 \%)\end{array}$ & $\begin{array}{l}0.685(0.458- \\
1.023) 0.064\end{array}$ & 2.601 & 0.1068 \\
\hline & & controls & 120 & $\begin{array}{l}7 \\
(5.83 \%)\end{array}$ & $\begin{array}{l}60 \\
(50.00 \%)\end{array}$ & $\begin{array}{l}53 \\
(44.17 \%)\end{array}$ & & & $\begin{array}{l}74 \\
(30.83 \%)\end{array}$ & $\begin{array}{l}166 \\
(69.17 \%)\end{array}$ & & 3.561 & 0.0592 \\
\hline \multirow[t]{2}{*}{ rs1800876 } & $\mathrm{T} / \mathrm{C}$ & AF & 119 & $\begin{array}{l}23 \\
(19.33 \%)\end{array}$ & $\begin{array}{l}59 \\
(49.58 \%)\end{array}$ & $\begin{array}{l}37 \\
(31.09 \%)\end{array}$ & 0.082 & $\begin{array}{l}1.122(0.652-1.932) \\
0.678\end{array}$ & $\begin{array}{l}105 \\
(44.12 \%)\end{array}$ & $\begin{array}{l}133 \\
(55.88 \%)\end{array}$ & $\begin{array}{l}1.298(0.900- \\
1.872) 0.162\end{array}$ & 5.502 & 0.0190 \\
\hline & & controls & 119 & $\begin{array}{l}11 \\
(9.24 \%)\end{array}$ & $\begin{array}{l}68 \\
(57.14 \%)\end{array}$ & $\begin{array}{l}40 \\
(33.62 \%)\end{array}$ & & & $\begin{array}{l}90 \\
(37.82 \%)\end{array}$ & $\begin{array}{l}148 \\
(62.18 \%)\end{array}$ & & 0.036 & 0.9520 \\
\hline \multirow[t]{2}{*}{ sc5244 } & $\mathrm{C} / \mathrm{T}$ & $\mathrm{AF}$ & 126 & $\begin{array}{l}11 \\
(8.73 \%)\end{array}$ & $\begin{array}{l}44 \\
(34.92 \%)\end{array}$ & $\begin{array}{l}71 \\
(56.35 \%)\end{array}$ & 0.225 & $\begin{array}{l}0.859(0.518-1.426) \\
0.557\end{array}$ & $\begin{array}{l}66 \\
(26.19 \%)\end{array}$ & $\begin{array}{l}186 \\
(73.81 \%)\end{array}$ & $\begin{array}{l}1.017(0.677- \\
1.527) 0.934\end{array}$ & 1.180 & 0.2774 \\
\hline & & controls & 116 & $\begin{array}{l}5 \\
(4.31 \%)\end{array}$ & $\begin{array}{l}50 \\
(43.10 \%)\end{array}$ & $\begin{array}{l}61 \\
(52.59 \%)\end{array}$ & & & $\begin{array}{l}60 \\
(25.86 \%)\end{array}$ & $\begin{array}{l}172 \\
(74.14 \%)\end{array}$ & & 1.785 & 0.1816 \\
\hline \multirow[t]{2}{*}{ rs1885108 } & $\mathrm{A} / \mathrm{G}$ & $\mathrm{AF}$ & 126 & $\begin{array}{l}16 \\
(12.70 \%)\end{array}$ & $\begin{array}{l}60 \\
(47.62 \%)\end{array}$ & $\begin{array}{l}50 \\
(39.68 \%)\end{array}$ & 0.471 & $\begin{array}{l}0.732(0.434-1.234) \\
0.241\end{array}$ & $\begin{array}{l}92 \\
(36.51 \%)\end{array}$ & $\begin{array}{l}160 \\
(63.49 \%)\end{array}$ & $\begin{array}{l}0.805(0.560- \\
1.157) 0.241\end{array}$ & 0.093 & 0.7603 \\
\hline & & controls & 120 & $\begin{array}{l}19 \\
(15.83 \%)\end{array}$ & $\begin{array}{l}62 \\
(51.67 \%)\end{array}$ & $\begin{array}{l}39 \\
(32.50 \%)\end{array}$ & & & $\begin{array}{l}100 \\
(41.67 \%)\end{array}$ & $\begin{array}{l}140 \\
(58.33 \%)\end{array}$ & & 0.474 & 0.4911 \\
\hline
\end{tabular}


Table 3 Association between the CMA1 haplotypes and atrial fibrillation

\begin{tabular}{llllll}
\hline Name & Haplotype & Case (freq) & Control (freq) & Odds Ratio (95\%Cl) & $p$ \\
\hline Hap1 & CGCTA & $23(0.097)$ & $33(0.145)$ & $0.633(0.360-1.116)$ & 0.112 \\
Hap2 & CGTTA & $1(0.004)$ & $5(0.020)$ & $0.212(0.024-1.840)$ & 0.122 \\
Hap3 & TACCA & $2(0.010)$ & $4(0.017)$ & $0.123-3.057)$ & $0.995(0.638-1.550)$ \\
Hap4 & TACTG & $50(0.214)$ & $49(0.214)$ & $0.178(0.042-0.749)$ & 0.981 \\
Hap5 & TATTG & $2(0.010)$ & $12(0.051)$ & $1.092(0.704-1.694)$ & 0.008 \\
Hap6 & TGCCA & $54(0.229)$ & $49(0.213)$ & $1.090(0.228-5.203)$ & 0.695 \\
Hap7 & TGTCA & $3(0.014)$ & $3(0.013)$ & $1.668(1.132-2.458)$ & 0.914 \\
Hap8 & TGTTG & $95(0.404)$ & $67(0.290)$ & 0.009
\end{tabular}

Cl Confidence interval, OR Odds ratio. The haplotype structure of the CMA1 gene was rs1956921 (C/T), rs1800875 (A/G), rs1800876 (T/C), rs5244 (C/T) and rs1885108 (A/G). Haplotypes with frequencies $<0.01$ were not included in the table

a genetically heterogeneous disease [25]. In the current study, we sequenced five SNPs of the CMA1 gene in 126 unrelated Han Chinese patients diagnosed with lone AF. To the best of our knowledge, this represents the first study to demonstrate the possible contribution of CMA1 polymorphisms to the pathogenesis of AF. We found a possible association between the rs1800875 GG genotype and an increased risk of AF. Haplotype analysis further demonstrated that the rs1800875-G haplotype (Hap 8 TGTTG) might lead to an increased risk of AF, while rs1800875-A (Hap 5 TATTG) was associated with a reduced risk of AF.

This case-control study demonstrated a significant difference in the frequencies of the CMA1 rs1800875 GG genotype between AF patients and controls, indicating that this genotype might be a susceptibility factor for $\mathrm{AF}$ in the Chinese Han population, and further suggesting that the function of the CMA1 gene may be modulated by this polymorphism. Orlowska-Baranowska et al. [26] found that the rs1800875 SNP was an independent predictor of left ventricular mass in male patients with aortic stenosis. Amir et al. reported [27] that rs1800875 was related to a non-ischemic etiology of heart failure, and that patients homozygous for the $G$ allele had a significantly greater reduction in left ventricular systolic function. Both of these studies indicated an association between rs1800875 and cardiac remodeling. However, few studies have investigated the molecular pathogenesis and functional role of the rs $1800875 \mathrm{G}$ allele in cardiac remodeling. Growing evidence suggests that cardiac Ang II formation is predominantly dependent on chymase $[9,10]$.

The present study found no significant associations between the genotype and allele distributions of the rs1800876, rs1885108, rs1956921, and rs5244 SNPs and AF. Previous reports also suggested that some SNPs had no effect on gene function and phenotype [28]. However, further investigations with larger sample sizes are needed to confirm these findings.

The main limitation of the current study was the relatively small number of patients. Furthermore, functional studies are required to elucidate the details of the molecular mechanisms whereby the SNP or haplotype affects the CMA1 gene. In addition, the present study only enrolled Chinese Han individuals from Hangzhou, and further studies are needed to determine if the results can be generalized to other racial groups and locations.

\section{Conclusion}

In summary, the results of this study may help in the identification of polymorphisms related to $\mathrm{AF}$ in the Chinese Han population. Some CMA1 polymorphisms appear to be associated with AF, and the rs 1800875 GG genotype might serve as a susceptibility factor for AF. A better understanding of the genetic mechanisms of $\mathrm{AF}$ will allow more accurate risk stratification of $\mathrm{AF}$ patients. The recurrence rates of AF are approximately $40-50 \%$ after a single procedure and $10-20 \%$ after multiple procedures (including medication, electrical cardioversion, or catheter ablation) [29], and the current results might provide clues to aid the development of personalized therapeutic strategies in these patients. However, the exact mechanisms underlying this risk increment remain poorly elucidated, and further studies are needed to clarify the roles of the rs 1800875 , rs1800876, rs1885108, rs1956921, and rs5244 CMA1 polymorphisms in AF.

\section{Abbreviations \\ AF: Atrial fibrillation; Ang II: Angiotensin II; BMl: Body mass index; CMA1: Chymase 1 gene; Glu: Glucose; LDL: Low density lipoprotein; OR: Odds ratio; PCR: Polymerase chain reaction; RAS: Renin-angiotensin system; SNPs: S ingle nucleotide polymorphisms; TC: Total cholesterol; TG: Triglyceride}

\section{Acknowledgements}

The authors are greatly indebted to the patients and their families who agreed to participate and reviewers for their helpful comments in this study. The authors thankfully acknowledge the support of the dissertation grant.

\section{Authors' contributions}

DCZ, YWC, JXW, JBS, YSS, LRZ \& XDX designed the work and interpreted the data. DCZ, YWC \& JXW performed the statistical analyses, interpreted the data and drafted the manuscript. XDX \& LRZ revised the manuscript critically and provided continuous guidance throughout the study. JBS \& YSS 
collected the data and did the experiments. All authors read and approved the final manuscript.

\section{Funding}

This research was supported by funds from the National Natural Science Foundation of China (81270002), National Natural Science Foundation of China (81873484) and Natural Science Foundation of Zhejiang Province (LZ16H0200001). These funds had no role in the design of the study and collection, analysis, and interpretation of data and in writing the manuscript.

\section{Availability of data and materials}

The dataset analyzed during the current study are available from the corresponding author on reasonable request.

\section{Ethics approval and consent to participate}

The study conforms to the principles of the Declaration of Helsinki involving human subjects, and is approved by the Ethics Committee of the First Affiliated Hospital, School of Medicine, Zhejiang University (2016496). All participants signed the written informed consents form.

\section{Consent for publication}

Not applicable.

\section{Competing interests}

The authors declare that they have no competing interests.

Received: 6 July 2019 Accepted: 5 December 2019

Published online: 30 December 2019

\section{References}

1. Fuster V, Ryden LE, Cannom DS, Crijns HJ, Curtis AB, Ellenbogen KA, et al. 2011 ACCF/AHA/HRS focused updates incorporated into the ACC/AHA/ESC 2006 Guidelines for the management of patients with atrial fibrillation: a report of the American College of Cardiology Foundation/American Heart Association Task Force on Practice Guidelines developed in partnership with the European Society of Cardiology and in collaboration with the European Heart Rhythm Association and the Heart Rhythm Society. J Am Coll Cardiol. 2011;57(11):e101-98.

2. Armaganijan L, Lopes RD, Healey JS, Piccini JP, Nair GM, Morillo CA. Do omega-3 fatty acids prevent atrial fibrillation after open heart surgery? A meta-analysis of randomized controlled trials. Clinics (Sao Paulo). 2011; 66(11):1923-8

3. Saritas A, Kandis H, Baltaci D, Erdem I. Paroxysmal atrial fibrillation and intermittent left bundle branch block: an unusual electrocardiographic presentation of mad honey poisoning. Clinics (Sao Paulo). 2011;66(9):1651-3.

4. Evans W, Swann P. Lone auricular fibrillation. Br Heart J. 1954;16(2):189-94

5. Chen LY, Shen WK. Epidemiology of atrial fibrillation: a current perspective. Heart Rhythm. 2007:4(3 Suppl):S1-6.

6. Lubitz SA, Sinner MF, Lunetta KL, Makino S, Pfeufer A, Rahman R, et al. Independent susceptibility markers for atrial fibrillation on chromosome 4q25. Circulation. 2010;122(10):976-84

7. Healey JS, Morillo CA, Connolly SJ. Role of the renin-angiotensinaldosterone system in atrial fibrillation and cardiac remodeling. Curr Opin Cardiol. 2005;20(1):31-7.

8. Hall JE, Brands MW, Henegar JR. Angiotensin II and long-term arterial pressure regulation: the overriding dominance of the kidney. J Am Soc Nephrol. 1999;10(Suppl 12):S258-65.

9. Ahmad S, Varagic J, VonCannon JL, Groban L, Collawn JF, Dell'Italia L, et al. Primacy of cardiac chymase over angiotensin converting enzyme as an angiotensin-(1-12) metabolizing enzyme. Biochem Biophys Res Commun. 2016;478(2):559-64.

10. Dell'Italia LJ, Husain A. Dissecting the role of chymase in angiotensin II formation and heart and blood vessel diseases. Curr Opin Cardiol. 2002; 17(4):374-9.

11. Ahmad S, Varagic J, Groban L, Dell'Italia L, Nagata S, Kon ND, et al. Angiotensin-(1-12): a chymase-mediated cellular angiotensin II substrate. Curr Hypertens Rep. 2014;16(5):429.

12. Dell'Italia LJ, Meng QC, Balcells E, Wei CC, Palmer R, Hageman GR, et al. Compartmentalization of angiotensin $\|$ generation in the dog heart. Evidence for independent mechanisms in intravascular and interstitial spaces. J Clin Invest. 1997;100(2):253-8.
13. Baker KM, Booz GW, Dostal DE. Cardiac actions of angiotensin II: role of an intracardiac renin-angiotensin system. Annu Rev Physiol. 1992;54:227-41.

14. Takai S, Sakaguchi M, Jin D, Yamada M, Kirimura K, Miyazaki M. Different angiotensin II-forming pathways in human and rat vascular tissues. Clin Chim Acta. 2001;305(1-2):191-5.

15. Hossny EM, Amr NH, Elsayed SB, Nasr RA, Ibraheim EM. Association of polymorphisms in the mast cell chymase gene promoter region (-1903 g/ a) and (TG)n(GA)m repeat downstream of the gene with bronchial asthma in children. J Investig Allergol Clin Immunol. 2008;18(5):376-81.

16. Kokkonen JO, Lindstedt KA, Kovanen PT. Role for chymase in heart failure: angiotensin II-dependent or -independent mechanisms? Circulation. 2003; 107(20):2522-4.

17. Orlowska-Baranowska E, Gora J, Baranowski R, Stoklosa P, Gadomska vel Betka L, Pedzich-Placha E, et al. Association of the common genetic polymorphisms and haplotypes of the chymase gene with left ventricular mass in male patients with symptomatic aortic stenosis. PLoS One. 2014; 9(5):e96306.

18. Takai S, Miyazaki M. Application of a chymase inhibitor, NK3201, for prevention of vascular proliferation. Cardiovasc Drug Rev. 2003;21(3):185-98.

19. Matsumoto T, Wada A, Tsutamoto T, Ohnishi M, Isono T, Kinoshita M. Chymase inhibition prevents cardiac fibrosis and improves diastolic dysfunction in the progression of heart failure. Circulation. 2003;107(20): 2555-8

20. Takai S, Jin D. Improvement of cardiovascular remodelling by chymase inhibitor. Clin Exp Pharmacol P. 2016;43(4):387-93.

21. Parvez B, Darbar D. Lone AF - etiologic factors and genetic insights into Pathophysiolgy. J Atr Fibrillation. 2010;3(1):236.

22. Wu Y, Yang $H$, Yang B, Yang $K$, Xiao C. Association of polymorphisms in prolylcarboxypeptidase and chymase genes with essential hypertension in the Chinese Han population. J Renin-Angiotensin-Aldosterone Syst. 2013; 14(3):263-70.

23. Gross-Bellard MM, Oudet $P$, Chambon P. Isolation of high-molecular-weight DNA from mammalian-cells. Eur J Biochem. 1973;36(1):32-8.

24. Liang YH, Chen XL, Yu ZS, Chen CY, Bi S, Mao LG, et al. Deletion analysis of SMN1 and NAIP genes in southern Chinese children with spinal muscular atrophy. J Zhejiang Univ Sci B. 2009;10(1):29-34.

25. Darbar D, Herron KJ, Ballew JD, Jahangir A, Gersh BJ, Shen WK, et al. Familial atrial fibrillation is a genetically heterogeneous disorder. J Am Coll Cardiol. 2003:41(12):2185-92.

26. Parikh SM, Mammoto T, Schultz A, Yuan HT, Christiani D, Karumanchi SA, et al. Excess circulating angiopoietin-2 may contribute to pulmonary vascular leak in sepsis in humans. PLoS Med. 2006;3(3):e46.

27. Amir RE, Amir O, Paz H, Sagiv M, Mor R, Sagiv M, et al. Genotype-phenotype associations between chymase and angiotensin-converting enzyme gene polymorphisms in chronic systolic heart failure patients. Genet Med. 2008; 10(8):593-8.

28. Shastry BS. SNPs: impact on gene function and phenotype. Methods Mol Biol. 2009:578:3-22.

29. Hong K, Xiong Q. Genetic basis of atrial fibrillation. Curr Opin Cardiol. 2014; 29(3):220-6.

\section{Publisher's Note}

Springer Nature remains neutral with regard to jurisdictional claims in published maps and institutional affiliations.

Ready to submit your research? Choose BMC and benefit from:

- fast, convenient online submission

- thorough peer review by experienced researchers in your field

- rapid publication on acceptance

- support for research data, including large and complex data types

- gold Open Access which fosters wider collaboration and increased citations

- maximum visibility for your research: over $100 \mathrm{M}$ website views per year

At BMC, research is always in progress.

Learn more biomedcentral.com/submissions 